\title{
Gastrointestinal Parasites in the Waved Albatross (Phoebastria irrorata) of Galápagos
}

\begin{abstract}
Gustavo Jiménez-Uzcátegui, ${ }^{1}$ María Soledad Sarzosa, ${ }^{1,2}$ Edison Encalada, ${ }^{2}$ Richar Rodríguez-Hidalgo, ${ }^{2,3}$ Maritza Celi-Erazo, ${ }^{3}$ Christian Sevilla, ${ }^{4}$ and Kathryn P. Huyvaert ${ }^{5,6}{ }^{1}$ Department of Sciences, Charles Darwin Foundation, Puerto Ayora, Santa Cruz, Galápagos, Ecuador; ${ }^{2}$ Clinical Pathology Laboratory, Central University of Ecuador, Quito, Ecuador; ${ }^{3}$ International Center of Zoonoses, Central University of Ecuador, Quito, Ecuador; ${ }^{4}$ Galápagos National Park Directorate, Puerto Ayora, Santa Cruz, Galápagos, Ecuador; ${ }^{5}$ Department of Fish, Wildlife, and Conservation Biology, 1474 Campus Delivery, Colorado State University, Fort Collins, Colorado 80523, USA; ${ }^{6}$ Corresponding author (email: kate.huyvaert @ colostate.edu)
\end{abstract}

ABSTRACT: Using a fecal flotation technique, we detected three genera of endoparasites in the critically endangered Waved Albatross (Phoebastria irrorata) of Galápagos. These genera were Contracaecum, Tetrabothrius, and Cardiocephaloides. Juvenile albatrosses were more likely to be infected than adults, but we found no effect of sex or mass on infection probability.

The Waved Albatross (Phoebastria irrorata) is a long-lived, pelagic seabird endemic to Ecuador. The vast majority $(\sim 99.9 \%)$ of birds breed on Española Island, Galápagos Archipelago. The species is considered critically endangered, given its limited geographic distribution and recent declines in population size and apparent survival (International Union for Conservation of Nature 2013). Although the principal threat is mortality as bycatch in fisheries in continental coastal waters (Awkerman et al. 2006), the El Niño Southern Oscillation-mediated effects on vital rates and pathogens may also contribute to observed declines.

Disease can have disastrous consequences for vulnerable albatross populations by hastening mortality or reproductive failures that contribute to demographic change (Weimerskirch 2004). Disease in albatrosses is not well documented, in part, because it can be difficult to detect in species that spend only a short time on land, often on remote islands. Ectoparasites are most often described affecting albatrosses, though bacteria, viruses, fungi, and endoparasites are also represented (Barbosa and Palacios 2009). Ectoparasites are present in nests and on breeding adult Waved Albatrosses (K.P.H. pers. obs.), but endoparasites have not been considered in detail.

We surveyed live Waved Albatrosses for gastrointestinal parasites and tested effects of sex, age (juvenile or adult), and mass on the probability of infection with one or more parasites. We expected males to be more frequently infected, given an apparently broader foraging range ( $\mathrm{S}$. Cruz unpubl. data), stronger association with fisheries (Awkerman et al. 2006), and generally larger body size. We also hypothesized that adults would be more frequently parasitized given their greater cumulative exposure.

We collected cloacal swab samples from 229 Waved Albatrosses. Birds not already carrying a band were banded, and weight, tarsus, and culmen measurements were taken to determine sex (Awkerman et al. 2007). We collected samples from 205 adults in May (78 males, 82 females, and 45 undetermined sex) and 24 juveniles in November 2011 from breeding colonies on Española $\left(1^{\circ} 23^{\prime} \mathrm{S}, 89^{\circ} 35^{\prime} \mathrm{W}\right)$. Swab samples were fixed in $10 \%$ formalin, stored in cryovials at $4 \mathrm{C}$, and analyzed in laboratories at the Charles Darwin Foundation and the International Zoonosis Center at Central University of Ecuador (Quito). Samples were processed by using a modified McMaster flotation technique (Sloss and Kemp 1978) and microscopy; samples were of insufficient 
volume to quantify the intensity of infection. Any parasite proglottids or eggs that were encountered were measured by using an eyepiece micrometer, recorded digitally, and identified to genus using descriptive information on the life history and morphology of parasite genera infecting this and other marine bird taxa (Cordero del Campillo et al. 1999; Garbin et al. 2007; Fredes et al. 2008; J. Mendoza and L. Sánchez pers. comm.).

We explored the associations between infection status and sex, age, and mass in three separate logistic regression analyses. We considered two models in each analysis: one incorporating an effect of the predictor variable of interest and a second model of no effect (i.e., null model). We used the small sample sizecorrected version of Akaike's information criterion and their differences to rank the two models (Burnham and Anderson 2002). We used Akaike weights $\left(w_{i}\right)$ as measures of the probability of each model and their ratio (evidence ratio $[\mathrm{ER}]$ ) for inference.

Of 229 samples analyzed, 32 (14\%) were positive, including 25 adults (12\%) and seven (29\%) juveniles. We detected evidence of three genera of gastrointestinal parasite: eggs $(57 \mu$ long by $47 \mu$ wide, on average) of the genus Contracaecum
(Nematoda) in 13 samples (41\%); eggs and proglottids $(71 \times 52 \mu$ and $20 \times 5 \mathrm{~mm}$, on average, respectively) of the genus Tetrabothrius (Cestoda) in seven albatrosses (22\%); and eggs $(52 \times 45 \mu$, on average) of the genus Cardiocephaloides (Trematoda) in 12 hosts (38\%). No sample had evidence of parasitism with two genera. The model incorporating an effect of age was three times more likely than the model of no effect $\left(w_{i}=0.75\right.$ and $\mathrm{ER}=3.04$; Table 1); juveniles were more likely to have an endoparasite than adults. The models of no effect were higher ranked than those incorporating sex or mass effects (Table 1).

Our findings corroborate reports of several species of Tetrabothrius infecting albatrosses (overview in Schmidt 1986), including Tetrabothrius strangulatus found among specimens collected from a Waved Albatross (Baylis 1914). Contracaecum spp. are commonly seen in fisheating birds, including albatrosses (e.g., Garbin et al. 2007) and other species of marine birds from Galápagos (CarreraJátiva et al. 2014). Intermediate stages of Contracaecum spp. could be present in some species of widely distributed crustacea or fish (Cordero del Campillo et al. 1999) on which these birds feed. Cardiocephaloides brandesii has been reported

TABLE 1. Pairs of logistic regression models and rankings examining the effects of sex, age (juvenile or adult), and mass on the probability of detecting an endoparasite in a sample collected from a Waved Albatross (Phoebastria irrorata).

\begin{tabular}{lccccccc}
\hline Model $^{\mathrm{a}}$ & $n$ & $K$ & $-2 \mathrm{LL}$ & AICc & $\Delta$ AICc & $w_{i}$ & ER \\
\hline Sex & & & & & & & \\
$\quad$ No effect & 161 & 1 & 124.68 & 126.71 & 0.00 & 0.73 & 0.36 \\
$\quad$ Effect & & 2 & 124.33 & 128.74 & 2.03 & 0.27 & \\
$\quad \begin{array}{l}\text { Age } \\
\quad \text { No effect }\end{array}$ & 229 & 1 & 185.26 & 187.28 & 2.23 & 0.25 & 3.04 \\
$\quad$ Effect & & 2 & 181.00 & 185.05 & 0.00 & 0.75 & \\
Mass & 165 & 1 & 125.79 & 127.82 & 0.00 & 0.73 & 0.37 \\
$\quad$ No effect & & 2 & 125.72 & 129.80 & 1.99 & 0.27 & \\
$\quad$ Effect & & & & & & \\
\hline
\end{tabular}

a The sample size $(n)$, number of parameters $(K),-2$ times the log likelihood (-2LL), and bias-corrected Akaike information criterion values (AICc) are listed. Models are ranked by their AICc differences ( $\mathrm{AICc}$ ) relative to the best model in the pair of models. The Akaike weights (wi) are model probabilities given the model set, and the data and the evidence ratio (ER) is the ratio of the weights of the two models of interest. For example, the model incorporating an age effect is approximately three times more likely than the model without an age effect. 
from a dead Waved Albatross in the field (J. Mendoza and L. Sánchez pers. comm.), but to our knowledge, this is the first report of this genus from live albatrosses.

We found support for the idea that juveniles were more likely to be infected with gastrointestinal parasites than breeding-age adults ( $\geq 5 \mathrm{yr}$ old). This could be linked to the species' foraging ecology: parents feed chicks with regurgitant, including fish, squid, and crustaceans (Harris 1973), groups that serve as intermediate hosts for parasites from all three of these genera (Cordero del Campillo et al. 1999). We detected parasites in juveniles more often, perhaps because their immune response may not be as well developed as adults, if maternally derived protection has waned (Boulinier and Staszewski 2008) and their own immune systems had not fully developed when we sampled them at $\sim 5$ mo of age.

The health of pelagic species, such as albatrosses, may serve as an early indicator of a marine ecosystem's resilience to change (Piatt et al. 2007). Our findings provide a foundation for future work on the implications of parasitism for Waved Albatrosses and the marine ecosystems they inhabit.

We thank the Galápagos National Park Directorate and the Charles Darwin Foundation for their continued support of our work. We thank Paulina Fernandez for assistance in the laboratory. We are grateful to collaborators, assistants, and volunteers who have worked with us on the Waved Albatross over the years. This publication is contribution 2101 of the Charles Darwin Foundation for the Galápagos Islands.

\section{LITERATURE CITED}

Awkerman JA, Huyvaert KP, Mangel J, Alfaro Shigueto J, Anderson DJ. 2006. Incidental and intentional catch threatens Galápagos waved albatross. Biol Conserv 133:483-489.

Awkerman JA, Westbrock MA, Huyvaert KP, Anderson DJ. 2007. Female-biased sex ratio arises after parental care in the sexually dimorphic Waved Albatross (Phoebastria irrorata). Auk 124:1336-1346.

Barbosa A, Palacios MJ. 2009. Health of Antarctic birds: A review of their parasites, pathogens, and diseases. Polar Biol 32:1095-1115.

Baylis HA. 1914. On a new cestode from an albatross. Proc Zool Soc Lond 1914:407-413.

Boulinier T, Staszewski V. 2008. Maternal transfer of antibodies: Raising immuno-ecology issues. Trends Ecol Evol 23:282-288.

Burnham KP, Anderson DR. 2002. Model selection and multimodel inference: A practical information-theoretic approach. Springer, New York, New York, 484 pp.

Carrera-Játiva P, Rodríguez-Hidalgo R, Sevilla C, Jiménez-Uzcátegui G. 2014. Gastrointestinal parasites in the Galápagos Penguin Spheniscus mendiculus and the Flightless Cormorant Phalacrocorax harrisi in the Galápagos Islands. Mar Ornithol 42:77-80.

Cordero del Campillo M, Rojo FA, Martínez AR, Sánchez C, Hernández S, Navarrete I, Díez P, Quiroz H, Carvalho M. 1999. Parasitología veterinaria. McGraw Hill-Interamericana, Madrid, Spain, 968 pp.

Fredes F, Raffo E, Muñoz P, Herrera M, Godoy C. 2008. Fauna parasitaria gastrointestinal en el Pingüino Adelia (Pygoscelis adeliae) de zona antártica especialmente protegida (ZAEP No. 150). Parasitol Latinoam 63:64-68.

Garbin LE, Navone GT, Diaz JI, Cremonte F. 2007. Further study of Contracaecum pelagicum (Nematoda: Anisakidae) in Spheniscus magellanicus (Aves: Spheniscidae) from Argentinean coasts. J Parasitol 93:143-150.

Harris MP. 1973. The biology of the Waved Albatross Diomedea irrorata of Hood Island, Galapagos. Ibis 115:483-510.

International Union for Conservation of Nature (IUCN). 2013. IUCN red list of threatened species. Version 2013.2. http://www.iucnredlist. org. Accessed May 2014

Piatt J, Sydeman W, Browman H. 2007. Introduction: A modern role for seabirds as indicators. Mar Ecol Prog Ser 352:199-204.

Schmidt GD. 1986. Handbook of tapeworm identification. CRC Press, Boca Raton, Florida, 675 pp.

Sloss MW, Kemp RL. 1978. Veterinary clinical parasitology. Iowa State University Press, Ames, Iowa, 274 pp.

Weimerskirch H. 2004. Diseases threaten southern ocean albatrosses. Polar Biol 27:374-379.

Submitted for publication 20 June 2014

Accepted 2 December 2014. 